\title{
Diane Ravitch \\ The Death and Life of the Great American School System: How Testing and Choice are Undermining Education
}

New York: Basic Books, 2010. 283 pp.

\section{W.P.J. Millar}

London, Ont.

This book begins with an account of a surprising intellectual journey. Diane Ravitch looks back over her forty-odd years of writing about educational issues, historical and contemporary, in the United States. And though long an advocate of "testing, accountability, choice, and markets" (1) for the reform of the public education system, she admits that she has made "a very slow U-turn" in her view of what actually constitutes reform, and how that is to be accomplished [see "An Interview with Diane Ravitch" at www.educationalpolicy.org/publications (Nov. 2010)]. She argues that these prescriptions have often been misused or are simply wrong, and she provides a forceful argument about their deleterious effects on the schools, interspersed with her proposals for fixing the system. There is a great deal of passionate writing in this book, and a dose of didacticism. The chapters take a more-or-less chronological path, though the organization tends to be wayward - central themes are picked up, dropped, and then returned to in several different places. But on the whole, the book offers an insider's critique that is well worth considering (as many readers of this journal will know, Ravitch was assistant secretary of education in the early 1990s and has been involved in various educational reform movements).

The book describes reform ideas going back to 1983 and the publication of $A$ Nation at Risk, a report commissioned by the Reagan administration that deplored the state of the nation's schools and their failure to provide an adequate education. It goes on to examine how various efforts were made throughout the country to address this "crisis." Several chapters provide examples of how, in places like New York City and San Diego, administrators and educators attempted to overhaul the school 
system. Their toolkit included maintaining tight administrative control over pedagogy, judging teachers and schools by the results of standardized testing, instituting merit pay, firing some staff and closing some schools that did not measure up, and opening other schools that competed with the regular public schools; in Ravitch's estimate, this "business model" led to wholly inappropriate methods of delivering and assessing education, and often to unfortunate results. This theme is again the focus of a chapter in which the author examines the question of accountability for education through testing, and in another that examines the role of philanthropic agencies such as the Gates Foundation in providing funds based on business models of how schools should work.

Ravitch describes the effect of No Child Left Behind, the federal legislation introduced by the Bush administration. This chapter focuses particularly on the establishment of standardized testing programs as the basis for allocating federal funds, and hammers home her conclusions that, despite expectations, NCLB was totally ineffective in raising standards. Yet another chapter examines the way in which charter schools, a keystone of school choice, actually threatened the standing of public education by siphoning off the best students, leaving the most difficult children, those needing the greatest attention, and those performing at low standards, to the regular schools. The concluding chapter summarizes the author's views on what public schools do not and should not do, and what kind of education they should provide.

Ravitch remains optimistic about the chances of a revitalized public education system. Purposefully echoing Jane Jacobs' famous title, she hopes that American education will "experience a renaissance" $(\mathrm{x})$. Whether or not one agrees with all her arguments, this is a timely and important contribution to debates over public education that are on-going for Canadian as well as American schools. 